\title{
SOLVENT FREE, ONE POT SYNTHESIS OF SYMMETRIC XANTHENE DYES AND THEIR ELECTROCHEMICAL STUDY
}

\author{
GHULAM SHABIR AND AAMER SAEED ${ }^{I *}$
}

Department of Chemistry, Quaid-I-Azam University, Islamabad 45320, Pakistan.

\begin{abstract}
The present paper reports the synthesis of xanthene dyes derivatives from 4, 4'-oxydiphthalic anhydride and 1, 4, 5, 8-naphthalenetetracarboxylic dianhydride (3a-e and 6a-e) with different substituted phenols via Friedel-Crafts acylation reaction in the presence of an ammonium chloride catalyst. The structures of all newly synthesized derivatives were confirmed by the chromatographic, spectral and microelemental data. Dianhydride derivatives with 3-N', N'-dimethylaminophenol (3d and 6d) and resorcinol (3e and 6e) have been found to be highly fluorescent. Electrochemical study was done to determine band gap energy, LUMO and HOMO level energy. Band gap and LUMO energy levels were found to be lowest in xanthene derivatives 3c and $\mathbf{6 c}$. Dyes $\mathbf{3 d} \mathbf{d}, \mathbf{3 e}, \mathbf{6 d}$ and $\mathbf{6 e}$ were found useful for differential staining of plant cells.
\end{abstract}

Keywords: Symmetric Xanthene dyes, Dianhydride, Chromatographic analysis, Electrochemical study.

\section{INTRODUCTION}

Xanthene dyes are extremely important class of dyes because of their wide range of biological and pharmaceutical properties, such as agricultural bactericide activity ${ }^{1}$, anti-inflammatory and anti viral ${ }^{2}$, antioxidant ${ }^{3}$, anticancer $^{4}$, cytotoxic ${ }^{5}$ and antiproliferative properties ${ }^{6}$. These are being utilized as antagonists for paralyzing action of zoxazolamine ${ }^{7}$ and in photodynamic therapy ${ }^{8,9}$. Besides this they are being used in dye lasers and in various photosensitized reactions. For their outstanding photophysical properties, xanthene dyes are very efficient laser dyes ${ }^{10}$ and as $\mathrm{pH}$ sensitive fluorescent materials for bioimaging ${ }^{11}$. Since xanthene dyes have a sensitizing effect, their applications for dye sensitized solar cells (DSSC) have been reported ${ }^{12-15}$ and as hole-transporting materials in organic light-emitting devices (OLEDs) ${ }^{16}$.

Due to the applicability of the xanthenes and benzoxanthenes, several synthetic protocols have been reported, including the reaction of alkylphenoxymagnesium halides with triethyl orthoformate ${ }^{17}$, the palladiumcatalysed cyclization of polycyclic aryltriflate esters ${ }^{18}$, the cyclocondensation reaction between 2-tetralone and 2-hydroxyarylaldehydes under acidic conditions ${ }^{19}$, and the reaction of the condensation of cyclic 1,3-diketones with aryl aldehydes catalysed by molybdate sulphonic acid ${ }^{20}$. Furthermore, 14-aryl14Hdibenzo [a,j] xanthene derivatives can be prepared by the condensation reaction of 2-naphthol with aryl aldehydes in the presence of different Lewis acids ${ }^{21-25}$ and Bronsted acids ${ }^{26-29}$. The objective of the current research was to synthesize highly fluorescent, thermally and photochemically stable xanthene dyes which could be used in preference over usual fluorescent dyes like fluorescein and rhodamine dyes via short green route. To this end two series of xanthene derivatives (3a-e and 6a-e) from 4,4'-Oxydiphthalic anhydride and 1,4,5,8-Naphthalenetetra- carboxylic dianhydride have been synthesized via Friedel craft reaction in the presence of ammonium chloride.

\section{EXPERIMENTAL}

Materials: 4, 4'-Oxydiphthalic anhydride and 1,4,5,8-Naphthalenetetracarboxylic dianhydride were obtained from Sigma Aldrich. Resorcinol, o-cresol, 3,5-dihydroxy benzoic acid, orcinol, and 3-N,N'dimethylamino phenol was obtained from BDH. Ammonium chloride was purchased from Merck. Solvents such as ethanol, ethyl acetate, DMF, acetone and methanol were common laboratory grade chemicals.

Methods: All raw materials and reagents used for analysis were of $99 \%$ purity. The ${ }^{1} \mathrm{H}-\mathrm{NMR}$ and ${ }^{13} \mathrm{C}-\mathrm{NMR}$ spectra were recorded in $\mathrm{D}_{2} \mathrm{O}$ using NMR Bruker DPX 300 spectrophotometer operating at $300 \mathrm{MHz}$. Splitting patterns were as follows: s (singlet), d (doublet), dd, (double, doublet), $\mathrm{t}$ (triplet), $\mathrm{m}$ (multiplet) and br (broad). Chemical shifts are reported in $\delta(\mathrm{ppm})$. The FTIR spectra were run in the single beam Nicolet FT-IR 100. Ultraviolet-visible (UV-VIS) spectra were recorded on a double beam Perkin-Elmer Lambda 900 UV-VIS-NIR spectrophotometer. The data were used to calculate the molar extinction coefficients for the compounds.

General Procedure:

In a $250 \mathrm{ml}$ round bottom flask a well mixed mixture of $0.308 \mathrm{gm}$ $(0.001 \mathrm{~mol})$ of $4,4^{\prime}$-oxydiphthalic anhydride (1) and substituted phenols (2a-e Scheme 1) $0.004 \mathrm{~mol}$ were taken and fused in oil bath at $180^{\circ} \mathrm{C}$. The fused melt was added $0.2 \mathrm{~g}$ of $\mathrm{NH}_{4} \mathrm{Cl}$ and stirred the reaction mixture mechanically at $180-190^{\circ} \mathrm{C}$ until the solid mass obtained. The solid mass was dissolved in $10 \mathrm{ml}$ of $5 \%$ sodium hydroxide solution. The solution was filtered to remove any insoluble impurities and filtrate was treated with $3 \mathrm{ml}$ of $30 \%$ hydrochloric acid and precipitated the dyes (3a-e). Similarly the derivatives of 1,4,5,8-Naphthalenetetracarboxylic dianhydride (6a-e) with substituted phenols (2a-e, Scheme 2) were synthesized by following the same procedure.

6,6'-oxybis (3',6'-dihydroxy-3-oxo-3H-spiro[isobenzofuran-1,9'xanthene]-1',8'-dicarboxylic acid) (3a)

Yellowish brown, m.p $>250^{\circ} \mathrm{C} ; \mathrm{R}_{\mathrm{f}}: 0.34$ (ethyl acetate: ethanol 1: 1); $\lambda_{\max }(\mathrm{nm}): 453$; FTIR (Neat) v: 3300-3500 (br, $\left.\mathrm{COOH}, \mathrm{OH}\right), 3130(\mathrm{C}=\mathrm{C}-\mathrm{H}$, str), 1782 (lactone $\mathrm{C}=\mathrm{O}$ ), 1753 (carboxylic $\mathrm{C}=\mathrm{O}), 1642(\mathrm{C}=\mathrm{C}), 1588(\mathrm{C}=\mathrm{C})$, 1128 (C-O), 853 (Ar-H, bend), 810 (Ar-H, bend) $\mathrm{cm}^{-1}$. ${ }^{1} \mathrm{H}-\mathrm{NMR} .{ }^{1} \mathrm{H}-\mathrm{NMR}$ (DMSO- $d, 300 \mathrm{MHz}) \delta(\mathrm{ppm}): 12.24(\mathrm{~s}, 4 \mathrm{H}, \mathrm{COOH}), 7.90(\mathrm{~d}, 2 \mathrm{H}), 7.30(\mathrm{~m}$, $2 \mathrm{H}), 7.13(\mathrm{~d}, 2 \mathrm{H}), 6.90(\mathrm{~s}, 4 \mathrm{H}), 6.75(\mathrm{~s}, 4 \mathrm{H}), 5.03(\mathrm{~s}, 2 \mathrm{H}, 4 \mathrm{OH}) .{ }^{13} \mathrm{C}-\mathrm{NMR}$ (DMSO $75 \mathrm{MHz}) \delta$ (ppm): 172.98, 168.92, 161.54, 156.45, 156.31, 151.17, 132.70, 130.85, 123.46, 119.69, 116.12, 113.98, 110.13, 107.96. Anal. Calcd. For $\mathbf{C}_{44} \mathbf{H}_{22} \mathbf{O}_{19}$ : C, $61.84 \mathrm{H}, 2.59$; Found: C, 61.96; H, 2.46.

6,6','-oxybis(3',6'-dihydroxy-1', 8'-dimethyl-3H-spiro[isobenzofuran1,9'-xanthen]-3-one) (3b)

Brownish red, m.p $>250{ }^{\circ} \mathrm{C} ; \mathrm{R}_{\mathrm{f}}: 0.37$ (ethyl acetate: ethanol 1: 1); $\lambda_{\max }$ (nm): 430; FTIR (Neat) v: $3323(\mathrm{br}, \mathrm{OH}), 3123(\mathrm{C}=\mathrm{C}-\mathrm{H}, \mathrm{str}), 1783$ (lactone $\mathrm{C}=\mathrm{O}), 1744$ (carboxylic $\mathrm{C}=\mathrm{O}), 1647(\mathrm{C}=\mathrm{C}), 1570(\mathrm{C}=\mathrm{C}), 1145(\mathrm{C}-\mathrm{O}), 853$ (Ar-H, bend), 812 (Ar-H, bend) $\mathrm{cm}^{-1} .{ }^{1} \mathrm{H}-\mathrm{NMR}$ (DMSO- $\left.d_{6}, 300 \mathrm{MHz}\right) \delta$ (ppm): $7.91(\mathrm{~d}, 2 \mathrm{H}), 7.20(\mathrm{~m}, 2 \mathrm{H}), 7.05(\mathrm{~d}, 2 \mathrm{H}), 6.40(\mathrm{~s}, 4 \mathrm{H}), 6.34(\mathrm{~s}, 4 \mathrm{H}), 5.16(\mathrm{~m}$, $4 \mathrm{H}, 4 \mathrm{OH}), 2.27(\mathrm{~s}, 12 \mathrm{H}) \cdot{ }^{13} \mathrm{C}-\mathrm{NMR}$ (DMSO $\left.75 \mathrm{MHz}\right) \delta(\mathrm{ppm}): 172.98,161.54$ $156.98,155.78,151.17,138.19,130.85,123.46,119.69,115.06,113.98$, 112.02, 103.15, 19.89. Anal. Calcd. For $\mathbf{C}_{44} \mathbf{H}_{30} \mathbf{O}_{11}$ : C, 71.93; H, 4.12; Found: C, 72.06; H, 4.05 .

6,6''-oxybis (4',5'-dimethyl-3 $H$-spiro[isobenzofuran-1,9'-xanthen]-3one) $(3 \mathrm{c})$

Violet, m.p $>250{ }^{\circ} \mathrm{C} ; \mathrm{R}_{\mathrm{f}}: 0.43$ (ethyl acetate: ethanol 1: 1); $\lambda_{\max }(\mathrm{nm}): 558$; FTIR (Neat) v: $3110(\mathrm{C}=\mathrm{C}-\mathrm{H}, \mathrm{str}), 1788$ (lactone $\mathrm{C}=\mathrm{O}), 1742$ (carboxylic $\mathrm{C}=\mathrm{O}), 1638(\mathrm{C}=\mathrm{C}), 1584(\mathrm{C}=\mathrm{C}), 1133(\mathrm{C}-\mathrm{O}), 850(\mathrm{Ar}-\mathrm{H}$, bend $), 818(\mathrm{Ar}-\mathrm{H}$, bend) $\mathrm{cm}^{-1}$. ${ }^{1} \mathrm{H}-\mathrm{NMR}$ (DMSO- $\left.d_{6}, 300 \mathrm{MHz}\right) \delta(\mathrm{ppm}): 7.92(\mathrm{~d}, 2 \mathrm{H}), 7.32(\mathrm{~d}$, $2 \mathrm{H}), 7.25(\mathrm{~m} .1 \mathrm{H}), 7.18(\mathrm{~d}, 4 \mathrm{H}), 7.03(\mathrm{~d}, 4 \mathrm{H}), 6.99(\mathrm{~m}, 4 \mathrm{H}), 2.43(\mathrm{~s}, 12 \mathrm{H})$. ${ }^{13} \mathrm{C}-\mathrm{NMR}$ (DMSO $\left.75 \mathrm{MHz}\right) \delta(\mathrm{ppm}): 172.98,161.51,151.89,148.49,131.61$, 131.46, 130.51, 126.77, 126.20, 125.48, 121.57, 118.82, 112.64, 15.55. Anal. Calcd. For $\mathbf{C}_{44} \mathbf{H}_{30} \mathbf{O}_{7}$ : C, 78.79; H, 4.51; Found: C, 78.91; H, 4.41.

6,6'-oxybis (3',6'-bis(dimethylamino)-3H-spiro[isobenzofuran-1,9'xanthen]-3-one) (3d)

Pink, m.p $>250^{\circ} \mathrm{C} ; \mathrm{R}_{\mathrm{f}}: 0.36$ (ethyl acetate: ethanol 1: 1); $\lambda_{\max }(\mathrm{nm}): 550$; FTIR (Neat) v: $3119(\mathrm{C}=\mathrm{C}-\mathrm{H}, \mathrm{str}), 1789$ (lactone $\mathrm{C}=\mathrm{O}), 1742$ (carboxylic $\mathrm{C}=\mathrm{O}), 1630(\mathrm{C}=\mathrm{C}), 1592(\mathrm{C}=\mathrm{C}), 1149(\mathrm{C}-\mathrm{O}), 859$ (Ar-H, bend), 793 (Ar$\mathrm{H}$, bend) $\mathrm{cm}^{-1} .{ }^{1} \mathrm{H}-\mathrm{NMR}$ (DMSO- $\left.d_{6}, 300 \mathrm{MHz}\right) \delta(\mathrm{ppm}): 7.82(\mathrm{~d}, 2 \mathrm{H}), 7.20$ $(\mathrm{m}, 2 \mathrm{H}), 7.18(\mathrm{~d}, 2 \mathrm{H}), 6.98(\mathrm{~d}, 2 \mathrm{H}), 6.40(\mathrm{~d}, 2 \mathrm{H}), 6.33(\mathrm{~s}, 2 \mathrm{H}), 2.91(\mathrm{~s}, 24 \mathrm{H})$ ${ }^{13} \mathrm{C}-\mathrm{NMR}$ (DMSO $\left.75 \mathrm{MHz}\right) \delta(\mathrm{ppm}): 172.98,161.51,153.89,153.87,148.49$, 131.61, 126.77, 125.06, 118.82, 112.64, 109.36, 107.01, 41.91. .Anal. Caled. For $\mathbf{C}_{48} \mathbf{H}_{42} \mathbf{N}_{4} \mathbf{O}_{7}:$ C, 73.27 ; H, 5.38; N, 7.12; Found: C, 74.70; H, 5.56; N, 7.32. 6,6'-Oxybis(3',6'-dihydroxy-3 -spiro[isobenzofuran-1,9'-xanthen]-3one) (3e) 
Yellow, m.p $>250^{\circ} \mathrm{C} ; \mathrm{R}_{\mathrm{r}}: 0.40$ (ethyl acetate: ethanol 1: 1); $\lambda_{\max }(\mathrm{nm}): 501$; FTIR (Neat) v: $3354(\mathrm{br}, \mathrm{OH}), 3130(\mathrm{C}=\mathrm{C}-\mathrm{H}, \mathrm{str}), 1788$ (lactone $\mathrm{C}=\mathrm{O}), 1754$ (carboxylic $\mathrm{C}=\mathrm{O}), 1633(\mathrm{C}=\mathrm{C}), 1581(\mathrm{C}=\mathrm{C}), 1130(\mathrm{C}-\mathrm{O}), 847(\mathrm{Ar}-\mathrm{H}$, bend), 801 (Ar-H, bend) $\mathrm{cm}^{-1} .{ }^{1} \mathrm{H}-\mathrm{NMR}$ (DMSO $\left.300 \mathrm{MHz}\right) \delta(\mathrm{ppm}): 7.91(\mathrm{~d}, 2 \mathrm{H})$, $7.20(\mathrm{~m}, 2 \mathrm{H}), 7.11(\mathrm{~d}, 2 \mathrm{H}), 7.03(\mathrm{~d}, 2 \mathrm{H}), 6.55(\mathrm{~d}, 2 \mathrm{H}), 6.48(\mathrm{~s}, 2 \mathrm{H}) .{ }^{13} \mathrm{C}-\mathrm{NMR}$ (DMSO $75 \mathrm{MHz}) \delta(\mathrm{ppm}): 172.98,161.51,153.89,153.87,148.49,131.61$, 126.77, 125.06, 118.82, 117.10, 112.64, 109.36, 107.01. Anal. Calcd. For $\mathbf{C}_{40} \mathbf{H}_{22} \mathbf{O}_{11}:$ C, 70.80; H, 3.27; Found: C, 70.91; H, 3.20.

3,3',6,6''-Tetrahydroxy-3',8'-dioxo-3',8'-dihydrodispiro[xanthene9,1'-isochromeno[6,5,4-def]isochromene-6',9''-xanthene]-1,1', $, 8,8$ ', tetracarboxylic acid (6a)

Brown, m.p $>250{ }^{\circ} \mathrm{C} ; \mathrm{R}_{\mathrm{f}}: 0.37$ (ethyl acetate: ethanol 1: 1); $\lambda_{\max }(\mathrm{nm}): 465$; FTIR (Neat) v: 3350-3500 (br, $\mathrm{COOH}, \mathrm{OH}), 3133(\mathrm{C}=\mathrm{C}-\mathrm{H}, \mathrm{str}), 1782$ (lactone $\mathrm{C}=\mathrm{O}), 1755$ (carboxylic $\mathrm{C}=\mathrm{O}), 1641(\mathrm{C}=\mathrm{C}), 1594(\mathrm{C}=\mathrm{C}), 1128(\mathrm{C}-\mathrm{O}), 836$ (Ar-H, bend), 817 (Ar-H, bend) $\mathrm{cm}^{-1}$. ${ }^{1} \mathrm{H}-\mathrm{NMR}$ (DMSO- $\left.d, 300 \mathrm{MHz}\right) \delta(\mathrm{ppm})$ : $14.12(\mathrm{~s}, 2 \mathrm{H}, \mathrm{br}), 8.35(\mathrm{~d}, 2 \mathrm{H}), 7.65(\mathrm{~d}, 2 \mathrm{H}), 6.97-6.99(\mathrm{~s}, 4 \mathrm{H}), 6.80(\mathrm{~s}, 4 \mathrm{H})$, 5.04 (s, 2H, br). ${ }^{13} \mathrm{C}-\mathrm{NMR}$ (DMSO $\left.75 \mathrm{MHz}\right) \delta(\mathrm{ppm}): 168.92,164.23,156.72$, $156.37,135.16,133.89,133.48,124.92,124.47,119.98,115.90,112.16$, 108.46. Anal. Calcd. For $\mathbf{C}_{42} \mathbf{H}_{20} \mathbf{O}_{18}: \mathrm{C}, 62.08 ; \mathrm{H}, 2.48$; Found: C, 62.15; H, 2.53 .

3,3 ",6,6"'-tetrahydroxy-1,1", 8,8 '"-tetramethyldispiro[xanthene-9,1'isochromeno[6,5,4-def]isochromene-6',9''-xanthene]-3',8'-dione (6b)

Yellowish red, m.p> $250{ }^{\circ} \mathrm{C} ; \mathrm{R}_{\mathrm{f}}: 0.48$ (ethyl acetate: ethanol 1: 1); $\lambda_{\text {max }}$ (nm): 481; FTIR (Neat) v: $3320(\mathrm{br}, \mathrm{OH}), 3140(\mathrm{C}=\mathrm{C}-\mathrm{H}$, str), 1794 (lactone $\mathrm{C}=\mathrm{O}), 1751$ (carboxylic $\mathrm{C}=\mathrm{O}), 1640(\mathrm{C}=\mathrm{C}), 1580(\mathrm{C}=\mathrm{C}), 1145(\mathrm{C}-\mathrm{O}), 860(\mathrm{Ar}-$ $\mathrm{H}$, bend), 815 (Ar-H, bend) $\mathrm{cm}^{-1}$. ${ }^{1} \mathrm{H}-\mathrm{NMR}$ (DMSO- $d$, $\left.300 \mathrm{MHz}\right) \delta(\mathrm{ppm})$ : 8.37 (d, 2H), 7.59 (d, 2H), 6.44 (s, 4H), 6.29 (s, 4H), 5.04 (s, 2H, br), 2.24 (s, $12 \mathrm{H}) .{ }^{13} \mathrm{C}-\mathrm{NMR}$ (DMSO $\left.75 \mathrm{MHz}\right) \delta(\mathrm{ppm}): 164.23,156.54,156.07,138.05$, $135.16,133.89,124.92,124.47,119.98,115.38,114.84,103.50,19.89$. Anal. Calcd. For $\mathbf{C}_{42} \mathbf{H}_{28} \mathbf{O}_{10}$ : C, 72.83; H, 4.07; Found: C, 72.77; H, 4.03.

4,4 ' $, 5,5$ ',-tetramethyldispiro[xanthene-9,1'-isochromeno[6,5,4-def] isochromene-6',9''-xanthene]-3',8'-dione (6c)

Bluish violet, m.p $>250{ }^{\circ} \mathrm{C} ; \mathrm{R}_{\mathrm{r}}: 0.39$ (ethyl acetate: ethanol 1: 1); $\lambda \quad(\mathrm{nm})$ : 521; FTIR (Neat) v: $3118(\mathrm{C}=\mathrm{C}-\mathrm{H}, \mathrm{str}), 1788$ (lactone $\mathrm{C}=\mathrm{O}), 1742$ (carboxylic $\mathrm{C}=\mathrm{O}), 1620(\mathrm{C}=\mathrm{C}), 1592(\mathrm{C}=\mathrm{C}), 1121(\mathrm{C}-\mathrm{O}), 858(\mathrm{Ar}-\mathrm{H}$, bend $), 807(\mathrm{Ar}-\mathrm{H}$, bend) $\mathrm{cm}^{-1}$. ${ }^{1} \mathrm{H}-\mathrm{NMR}$ (DMSO- $\left.d_{6}, 300 \mathrm{MHz}\right) \delta(\mathrm{ppm}): 8.37(\mathrm{~d}, 2 \mathrm{H}), 7.71(\mathrm{~d}$, $2 \mathrm{H}), 7.14(\mathrm{~d}, 4 \mathrm{H}), 7.03(\mathrm{~d}, 4 \mathrm{H}), 6.96(\mathrm{~m}, 2 \mathrm{H}), 2.53(\mathrm{~s}, 12 \mathrm{H}) .{ }^{13} \mathrm{C}-\mathrm{NMR}$ (DMSO $75 \mathrm{MHz}) \delta(\mathrm{ppm}): 164.23,152.65,135.01,134.94,131.86,131.41,127.47$, $125.88,125.09,124.89,121.93,119.34,15.55$. Anal. Calcd. For $\mathbf{C}_{42} \mathbf{H}_{28} \mathbf{O}_{6}: \mathbf{C}$ 80.24; H, 4.49; O, 15.27; Found: C, 80.24; H, 4.49; O, 15.27 .

3,3 ' , 6,6 ' '-tetrakis(dimethylamino)dispiro[xanthene- 9,1 ' isochromeno[6,5,4-def]|isochromene-6',9''-xanthene]-3',8'-dione (6d)

Reddish pink, m.p $>250^{\circ} \mathrm{C} ; \mathrm{R}_{\mathrm{f}}: 0.55$ (ethyl acetate: ethanol 1: 1); $\lambda_{\max }(\mathrm{nm})$ : 545; FTIR (Neat) v: $3130(\mathrm{C}=\mathrm{C}-\mathrm{H}$, str), 1786 (lactone $\mathrm{C}=\mathrm{O}), 1745$ (carboxylic $\mathrm{C}=\mathrm{O}), 1652(\mathrm{C}=\mathrm{C}), 1585(\mathrm{C}=\mathrm{C}), 1125(\mathrm{C}-\mathrm{O}), 847(\mathrm{Ar}-\mathrm{H}$, bend), $806(\mathrm{Ar}-\mathrm{H}$, bend) $\mathrm{cm}^{-1} .{ }^{1} \mathrm{H}-\mathrm{NMR}$ (DMSO-d, $\left.300 \mathrm{MHz}\right) \delta(\mathrm{ppm}): 8.30(\mathrm{~d}, 1 \mathrm{H}), 7.67(\mathrm{~d}$, $2 \mathrm{H}), 6.97(\mathrm{~d}, 4 \mathrm{H}), 6.48(\mathrm{~s}, 4 \mathrm{H}), 6.32(\mathrm{~d}, 4 \mathrm{H}), 2.90(\mathrm{~s}, 24 \mathrm{H}) .{ }^{13} \mathrm{C}-\mathrm{NMR}$ (DMSO $75 \mathrm{MHz}) \delta$ (ppm): $164.23,155.41,154.73,135.01,134.94,126.16,125.09$, $124.89,119.72,119.34,110.30,106.89,41.91$. Anal. Calcd. For $\mathbf{C}_{46} \mathbf{H}_{40} \mathbf{N}_{4} \mathbf{O}_{6}$ : C, 74.18; H, 5.41; N, 7.52; Found: C, 74.30; H, 5.33; N, 7.48.

3,3 ',6,6'-tetrahydroxydispiro[xanthene-9,1'-isochromeno[6,5,4-def] isochromene-6',9''-xanthenel-3',8'-dione (6e)

Reddish yellow, m.p $>250{ }^{\circ} \mathrm{C} ; \mathrm{R}_{\mathrm{r}}: 0.53$ (ethyl acetate: ethanol 1: 1); $\lambda$ (nm): 503; FTIR (Neat) v: 3315 (br, OH), $3118(\mathrm{C}=\mathrm{C}-\mathrm{H}, \mathrm{str}), 1790$ (lactone $\mathrm{C}=\mathrm{O}), 1750$ (carboxylic $\mathrm{C}=\mathrm{O}), 1650(\mathrm{C}=\mathrm{C}), 1576(\mathrm{C}=\mathrm{C}), 1140(\mathrm{C}-\mathrm{O}), 858$ (Ar-H, bend), 822 (Ar-H, bend) $\mathrm{cm}^{-1} .{ }^{1} \mathrm{H}-\mathrm{NMR}$ (DMSO- $\left.d, 300 \mathrm{MHz}\right) \delta(\mathrm{ppm})$ $8.18(\mathrm{~d}, 2 \mathrm{H}), 7.64(\mathrm{~d}, 2 \mathrm{H}), 7.07(\mathrm{~d}, 4 \mathrm{H}), 6.58(\mathrm{~s}, 4 \mathrm{H}, \mathrm{br}), 6.47(\mathrm{~d}, 4 \mathrm{H}) .{ }^{13} \mathrm{C}-\mathrm{NMR}$ (DMSO $75 \mathrm{MHz}) \delta(\mathrm{ppm}): 164.23,158.44,156.10,135.01,134.94,127.37$, $125.09,124.89,119.34,116.02,113.98,104.89$. Anal. Calcd. For $\mathbf{C}_{38} \mathbf{H}_{20} \mathbf{O}_{10}$ : C, $71.70 ; \mathrm{H}, 3.17$ Found: C, $71.83 ; \mathrm{H}, 3.10$

\section{RESULTS AND DISCUSSION}

Synthesis of Dyes (3a-e and 6a-e)

Symmetric xanthene dyes have been synthesized well in excellent yields and high purity in the solvent free conditions following the schemes 1 and 2 . The rational for the selection of these dyes for synthesis, is to acquire various scaffolds of this nature by derivatization which will help in the development of dye lasers, solar cells and fluorescent bioimaging. Here dyes 3a-e and 6a-e xanthene dyes have been synthesized comprising 4,4'-oxydiphthalic anhydride and 1, 4, 5, 8-naphthalene tetracarboxylic dianhydride condensed with 3,5-dihydroxybenzoic acid, Orcinol, o- Cresol, 3-N',N'-dimethylaminophenol and Resorcinol. Ammonium chloride was used as catalyst for condensation of substituted phenol with dianhydrides and the reaction occurred through Friedel craft acylation pathway due to the presence of $\mathrm{HCl}$ provided by the breakage of $\mathrm{NH}_{4} \mathrm{Cl}$. Intimate mixture of reactants was heated strongly at the $180^{\circ} \mathrm{C}$ to achieve cyclization and removal of water. Ratio between dianhydrides and substituted phenol 2a-e was adjusted 1:4 for reaction at both sides of reactants 1 and 4. Indication of completeness of the reaction was the formation of solid mass at high temperature, which was soluble in alkali solution. Physical data of these dyes is shown in table 1 .

Table 1: Physical Characteristics of Xanthene Dyes 3a-e and 6a-e

\begin{tabular}{|c|c|l|l|}
\hline S.No. & Dye & Colour in acidic medium & Colour in Basic medium \\
\hline 1 & 3a & Yellowish brown & Yellowish brown \\
\hline 2 & $\mathbf{3 b}$ & Yellowish Red & Red \\
\hline 3 & $\mathbf{3 c}$ & Colorless & Violet \\
\hline 4 & $\mathbf{3 d}$ & Pink & Pink \\
\hline 5 & $\mathbf{3 e}$ & Greenish Yellow & Greenish Yellow \\
\hline 5 & $\mathbf{6 a}$ & Yellowish brown & Yellowish brown \\
\hline 6 & $\mathbf{6 b}$ & Yellowish Red & Red \\
\hline 7 & $\mathbf{6 c}$ & Colorless & Violet \\
\hline 8 & $\mathbf{6 d}$ & Pink & Pink \\
\hline 9 & $\mathbf{6 e}$ & Greenish yellow & Greenish yellow \\
\hline
\end{tabular}

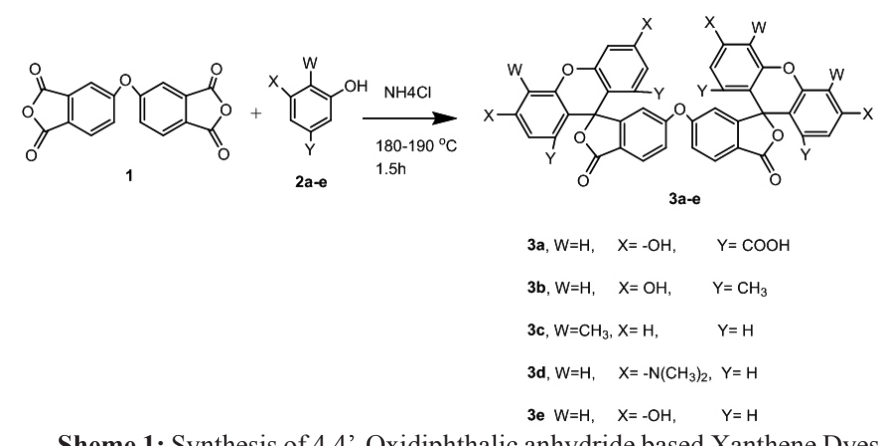
(3a-e).

Sheme 1: Synthesis of 4,4'-Oxidiphthalic anhydride based Xanthene Dyes
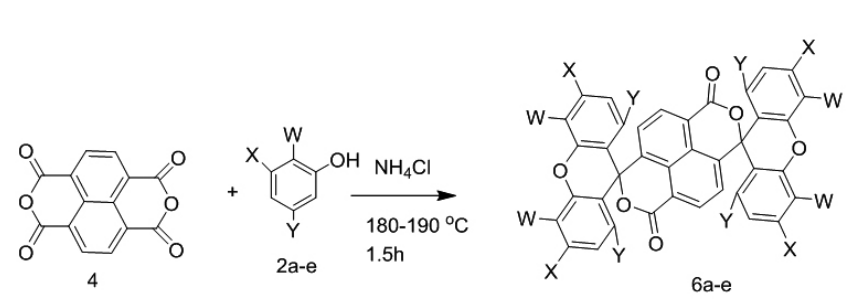

$6 a, W=H, \quad X=-O H, \quad Y=\mathrm{COOH}$

$6 \mathrm{~b}, \mathrm{~W}=\mathrm{H}, \quad \mathrm{X}=\mathrm{OH}, \quad \mathrm{Y}=\mathrm{CH} 3$

$6 c, W=\mathrm{CH} 3, \mathrm{X}=\mathrm{H}, \quad \mathrm{Y}=\mathrm{H}$

$6 \mathrm{~d}, \mathrm{~W}=\mathrm{H}, \quad \mathrm{X}=-\mathrm{N}(\mathrm{CH} 3) 2, \quad Y=\mathrm{H}$

6e $\mathrm{W}=\mathrm{H}, \quad \mathrm{X}=-\mathrm{O}, \quad \mathrm{Y}=\mathrm{H}$

Sheme 2: Symthesis of 1, 4, 5, 8- Naphthalenetetracarboxylic dianhydride based Xanthene Dyes (6a-e).

\section{Spectral Characterization of Dyes:}

The structures of newly synthesized xanthene dyes 3a-e and 6a-e were elucidated by UV, IR, LCMS and NMR studies. The UV-visible absorption spectra of the dyes $3 \mathbf{3}$-e and $\mathbf{6 a - e}\left(1 \times 10^{-6} \mathrm{M}\right)$ were obtained at room temperature in water (Figure 1 and 2) and the selected spectral data is summarized in Table 2 . 
Table 2; Wavelength of maximum absorption $\lambda_{\text {max }}$ of xanthene dyes (3a-e, 6a-e) in water.

\begin{tabular}{|c|c|c|}
\hline Dye & Solvent & $\lambda_{\text {max }}(\mathbf{n m})$ \\
\hline 3a & Water & 453 \\
\hline 3b & Water & 430 \\
\hline $\mathbf{3 c}$ & Water & 558 \\
\hline $\mathbf{3 d}$ & Water & 550 \\
\hline $\mathbf{3 e}$ & Water & 501 \\
\hline $\mathbf{6 a}$ & Water & 465 \\
\hline $\mathbf{6 b}$ & Water & 481 \\
\hline $\mathbf{6 c}$ & Water & 521 \\
\hline $\mathbf{6 d}$ & Water & 545 \\
\hline $\mathbf{6 e}$ & Water & 503 \\
\hline
\end{tabular}

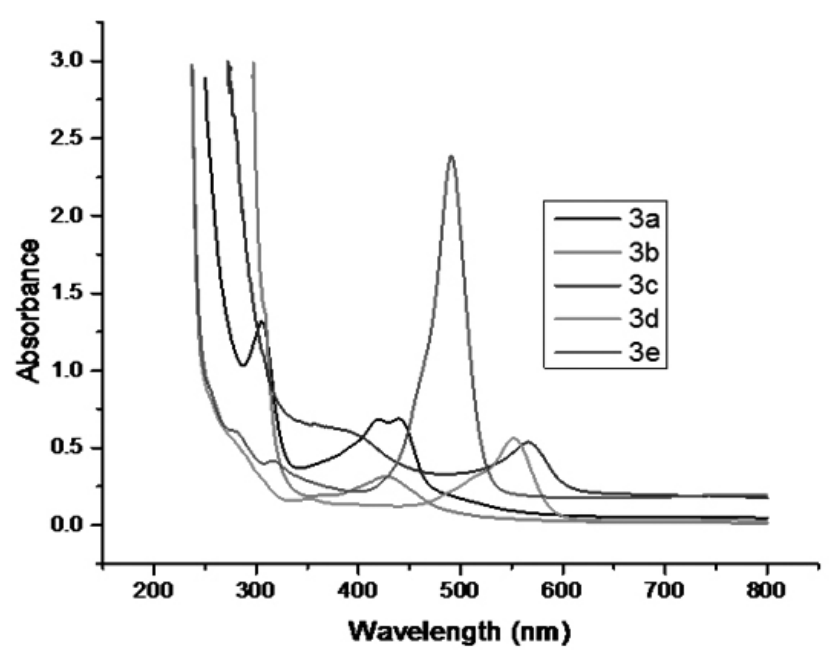

Figure 1: Combined UV-visible spectrum of 4,4'-Oxydiphthalic anhydride based xanthene dyes (3a-e).

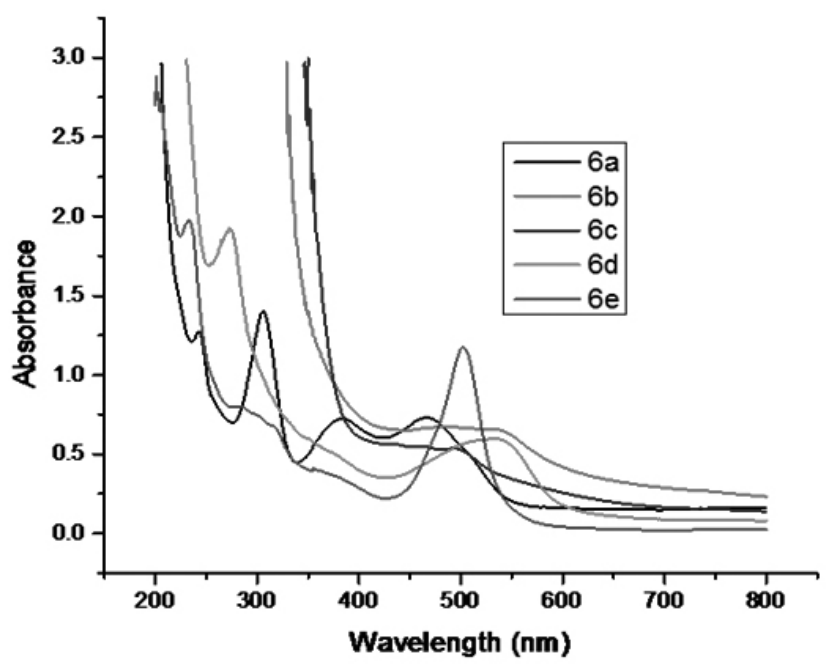

Figure 2: Combined UV-visible spectrum of 1, 4, 5, 8Naphthalenetetracarboxylic dianhydride based Xanthene Dyes (6a-e).

UV-visible spectra of all dyes (3a-e and 6a-e) were taken in water. It was observed from their UV-visible spectra of dyes 3a-e, that dye 3a exhibited two absorption maxima one at $300 \mathrm{~nm}$ and other at $453 \mathrm{~nm}$, while all other dyes showed one absorption band in the visible region (Figure 1). The derivatives of $1,4,5,8$-Naphthalenetetracarboxylic dianhydride $6 \mathrm{~b}$ and $6 \mathrm{c}$ provided only one absorption band, two bands for $6 \mathrm{~d}$ and $6 \mathrm{e}$, and three for $6 \mathrm{a}$. The bands at 260-300 nm for 3a-e and 6a-e are due to $\pi-\pi^{*}$ transition of the benzene rings common in all derivatives ${ }^{30}$. The $\lambda$ for $\mathbf{3 a}$ is $453 \mathrm{~nm}$ is due to $\pi$ - $\pi^{*}$ transitions of benzenoid structure formed in basic medium with increasing conjugation of rings with the opening of five membered lactone ring. Similarly the absorption band in $\mathbf{3 d}$ and $\mathbf{6 d}$ lies at $\mathbf{5 5 0} \mathrm{nm}$ and $\mathbf{5 4 5}$ giving them pink color. This is due more and more availability of electrons decreasing the energy difference between HOMO and LUMO energy levels. There by it has lager $\lambda_{\text {max }}$. In case of $6 \mathrm{a} \lambda$ is $465 \mathrm{~nm}$ while that $6 \mathrm{~b}, 6 \mathrm{c}$ and $6 \mathrm{e}$ is 481,521 and $503 \mathrm{~nm}$ respectively. All this is due to $\pi-\pi^{*}$ and $n-\pi *$ transitions of lone pairs and $\pi$-bonded electrons.

The FTIR spectra of xanthene dyes (3a-e and 6a-e) showed absorption bands due to $\mathrm{Ar}-\mathrm{H}, \mathrm{C}=\mathrm{O}$ of lactone, $\mathrm{C}=\mathrm{O}$ of carboxyl, $\mathrm{C}=\mathrm{C}$ and $\mathrm{C}-\mathrm{O}$, stretching and bending vibrations at 3118-3140, 1782-1796, 1742-1754, 1620-1652, $1576-1594,1121-1149,836-860$ and $793-818 \mathrm{~cm}^{-1}$ respectively. In case of dye $3 \mathrm{~d}$, lactone formation was confirmed by the appearance of peak at 1789 and opening of lactone peak at $1742 \mathrm{~cm}^{-1}$ due to carbonyl group of carboxyl, and are shifted to the high frequency region because of five membered lactone ring formation and these peaks are common in all dyes (Figure S1, Supporting information). Presence of peak at $1149 \mathrm{~cm}^{-1}$ was as a result of C-O-C functionality. The absorption bands at 1630, 1592 and $859 \mathrm{~cm}^{-1}$ depicted the present of $\mathrm{C}=\mathrm{C}$ stretching and bending vibrations respectively. FTIR spectrum of dye $6 \mathrm{e}$, showed a hydroxyl group peak at $3315 \mathrm{~cm}^{-1}$ and $3118 \mathrm{~cm}^{-1}$ which are due to hydroxyl group and $\mathrm{C}=\mathrm{C}-\mathrm{H}$ stretching vibrations (Figure 3 ). Five membered lactone ring formation and its opening was confirmed from the two peaks at 1790 and $1750 \mathrm{~cm}^{-1}$ in the spectrum. The other peaks in the spectrum are also in favour of the different functionalities in the molecule. In this way all other dyes functional groups have been confirmed from their FTIR spectra.

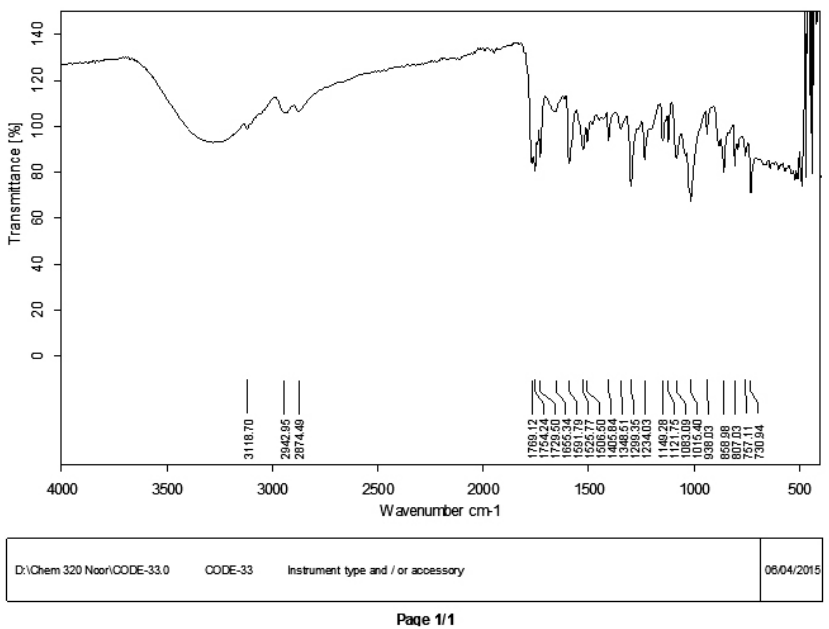

Figure 3: FTIR spectrum of dye $6 \mathrm{e}$

The ${ }^{1} \mathrm{H}-\mathrm{NMR}$ spectrum of compound 3d (Figure S2, Supporting information) showed $12 \mathrm{H}$ singlet peak at $2.83 \mathrm{ppm}$ and a $12 \mathrm{H}$ singlet at 2.99 ppm due to two $\mathrm{CH}_{3}$ substituents attached to the nitrogen atom. Singlet peak at $6.52 \mathrm{ppm}$ is due to aromatic proton adjacent to the oxygen atom of xanthene chromophore. Doublets at $6.77 \mathrm{ppm}$ and $6.99 \mathrm{ppm}$ are due to two mutually coupled aromatic protons attached to xanthenic part of the molecule. Doublet peaks at $7.34 \mathrm{ppm}$ and $7.73 \mathrm{ppm}$ are owing to the dianhydride part of the molecule, and a singlet at $7.05 \mathrm{ppm}$ is due to because of aromatic isolated proton at the phenyl ring of dianhydride. Difference among 3a-e series is due to condensed substituted phenols with biphenyl dianhydride. In $3 \mathrm{c}$ at $2.24 \mathrm{ppm}$ singlet due to $\mathrm{CH}_{3}$ protons and multiplet at $93-8.20(6 \mathrm{H} \mathrm{m})$, is seen due to $2 \mathrm{c}$ condensed with dianhydride. Similarly for $\mathbf{3 b}$ singlet peaks for $\mathrm{CH}_{3}$ and $\mathrm{Ar}-\mathrm{H}$ are present at 2.4 and $7.83 \mathrm{ppm}$.

In case of 6a-e dyes benzophenone dianhydride is condensed with different substituted phenols 2a-e. The difference in this series is because of different phenols. In dye 6e two doublets at 6.03 and 6.55 , and one singlet at $5.96 \mathrm{ppm}$, respectively, due to xanthene chromophore of ppm the molecule. Doublets at 7.22 and $7.44 \mathrm{ppm}$ are due to two mutually coupled protons at the naphthalene ring (Figure 4). The splitting pattern of the central core remains same throughout this series, but position is varied. A similar pattern was seen for $6 \mathrm{~d}$ except for that of two singlet peak at 2.35 and $2.99 \mathrm{ppm}$ due to condensed 
3-N'N'-dimethylamino phenol. The dye $6 \mathrm{~b}$ showed signals at 2.35 (s), 6.695 (s), and 6.45(s) ppm because of $\mathrm{CH}_{3}$ and $\mathrm{Ar}-\mathrm{H}$ of phenolic component $\mathbf{2 b}$ and $6 \mathrm{c}$ represented the signals splitting pattern different from $6 \mathrm{~b}$ owing to different phenolic isomer at $2.35(6 \mathrm{H} \mathrm{s}), 6.95(2 \mathrm{H} \mathrm{d}) 6.79(2 \mathrm{Hd}), 6.96(2 \mathrm{H} \mathrm{t}) 7.52(2 \mathrm{H} \mathrm{s})$ $\mathrm{ppm}$. In dye 6a aromatic signals splitting pattern was similar to that of $6 \mathrm{~b}$ except to that of carboxylic peak present at $11.35 \mathrm{ppm}$. The ${ }^{13} \mathrm{C}-\mathrm{NMR}$ spectrum of $6 \mathrm{e}$ showed ten aromatic carbon atoms in the range 102.42-169.40 ppm (Figure 5).
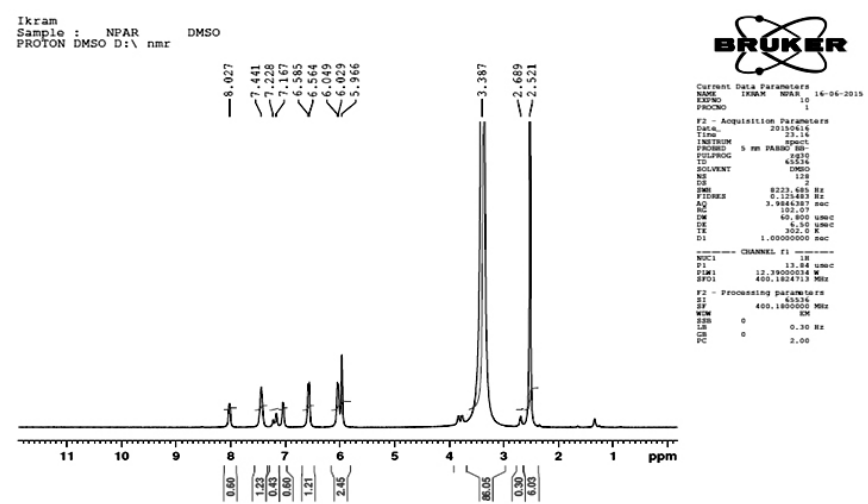

Figure 4: ${ }^{1} \mathrm{H}-\mathrm{NMR}$ spectrum of dye $6 \mathrm{e}$
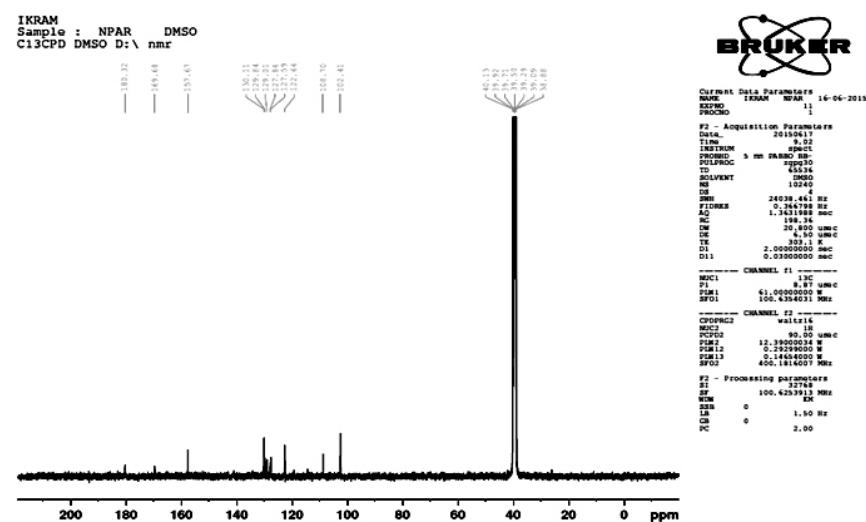

Figure 5: ${ }^{13} \mathrm{C}-\mathrm{NMR}$ spectrum of dye $6 \mathrm{e}$

Confirmation of the synthesized dyes were also confirmed by the LCMS analysis of dyes which showed strong $\mathrm{M}+1$ adduct peaks for the molecular weights of compounds (Figure 6 and S2)

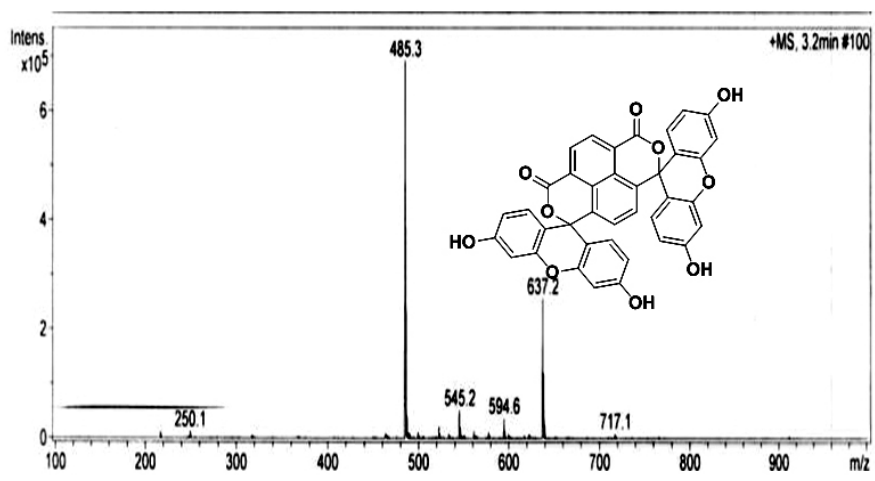

Figure 6: LCMS spectrum of xanthene dye 6e

Electrochemical Properties

The electrochemical characterization of these dyes was made by cyclic voltammetry (Figure 5 and S3 supporting informations) using water having 0.1 M TBAPF6 as a supporting electrolyte. All redox potentials, HOMO (highest occupied molecular orbital) and LUMO (lowest unoccupied molecular orbital) were determined from cyclic voltammograms.

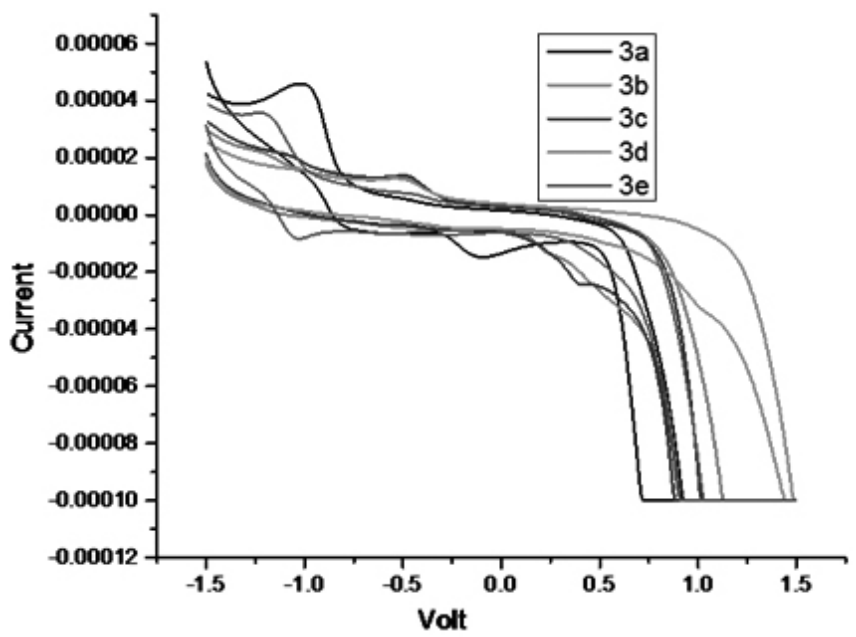

Figure 7: Combined cyclic voltammogram of xanthene dyes (3a-e)

Redox Potentials $\left(\mathbf{E}_{1 / 2}\right)$

Synthesized xanthene dyes (3a-e, 6a-e) showed oxidation and reduction potentials on conducting cyclic voltammetric analysis. From the cyclic voltammograms oxidation and reduction potentials were calculated ${ }^{31}$ to determine redox potentials $\left(\mathrm{E}_{\mathrm{r}}\right)$ as shown in table 3. The lowest redox potential was observed for 3 a dyes which have 3,5-dihydroxybenzoic acid condensed with 4, 4'-Oxydiphthalic anhydride and highest redox potential was seen for $3 \mathrm{c}$ and $3 \mathrm{~d}$ containing o-cresol. It can be visualized from the data in table 3 that xanthene dyes containing electron withdrawing groups have low redox potentials while those containing electron donating groups have a high redox potential values. Behavior of dyes based on 1, 4, 5, 8-Naphthalenetetracarboxylic dianhydride is different from dyes containing 4, 4'-Oxydiphthalic anhydride precursor. Here lowest $\mathrm{E}_{1 / 2}$ was found for $6 \mathrm{~d}$ containing dimethylamino group. Although this group is electron donating, but after donation of electron lactone ring is opened leaving two carboxylic groups directly linked to single aromatic nucleus which makes the ring highly deficient leading to lower redox values. Similar behavior was seen for dye 6e. Fused ring system in dyes 6a-e is responsible for their conversing behavior.

Lowest unoccupied molecular orbital (LUMO)

In order to calculate the absolute energies of LUMO level with respect to the vacuum level, the redox data are standardized to the ferrocene/ferricenium couple which has a calculated absolute energy of $-4.8 \mathrm{eV}^{32}$. The data related to LUMO level energies of dyes are presented in Table 3.

Table 3: LUMO energy levels of xanthene dyes (3a-e, 6a-e)

\begin{tabular}{|c|c|c|}
\hline S.No. & $\mathbf{E}_{\mathbf{1} / \mathbf{2}}(\mathbf{V})$ & LUMO $(\mathbf{e V})$ \\
\hline $3 \mathrm{a}$ & -0.350 & -4.45 \\
\hline $3 \mathrm{~b}$ & -0.125 & -4.67 \\
\hline $3 \mathrm{c}$ & -0.04 & -4.76 \\
\hline $3 \mathrm{~d}$ & +0.07 & -4.87 \\
\hline $3 \mathrm{e}$ & -0.02 & -4.78 \\
\hline $6 \mathrm{a}$ & -0.095 & -4.705 \\
\hline $6 \mathrm{~b}$ & -0.64 & -4.16 \\
\hline $6 \mathrm{c}$ & -0.05 & -4.805 \\
\hline $6 \mathrm{~d}$ & -0.820 & -4.39 \\
\hline $6 \mathrm{e}$ & -0.225 & -4.50 \\
\hline
\end{tabular}

It is inferred from LUMO energy levels, which vary from -4.16 to $-4.87 \mathrm{eV}$ that there electron donating groups on the xanthene motif decrease the energy of LUMO levels while electron withdrawing groups increase the energy of LUMO energy levels. The energy of LUMO levels can be varied only by increasing the delocalization of electrons through alternating single and 
double bonds and it is noticed that energy difference decreases with increasing conjugation and vice versa.

\section{Band Gap Energy (Eg)}

The optical band gap values are calculated using the standard procedure 33. The band gap energy is the span of energies that lies between the valence and conduction bands for insulators and semiconductors. Every solid has its own characteristic energy-band structure. This variation in band structure is responsible for the wide range of electrical characteristics observed in various materials ${ }^{34}$. Band gap energy of dyes is given in Table 3. The band gap energy varies from 2.19 to $2.87 \mathrm{eV}$ which is highest for dyes $3 \mathrm{a}, 3 \mathrm{~b}, 6 \mathrm{a}$ and minimum for dyes $3 \mathrm{c}, 3 \mathrm{~d}, 6 \mathrm{c}$ and $6 \mathrm{e}$ which depends upon substituents attached to xanthene chromophore as well as on the precursor (dianhydride) utilized for synthesis of dyes. In case of dyes 3a and 6a carboxylic group is attached to xanthene motif while $3 \mathrm{~d}$ and 6e have N, N'-dimethylamino- and hydroxyl groups which increases the electron density of chromophore and energy levels become close to each other and band gap energy is decreased.

Highest occupied molecular orbital (HOMO)

Table 4 depicts the highest occupied molecular orbital energy levels, which are calculated using the standard reported procedure [32]. Considering the energy range from -6.64 to $-7.54 \mathrm{eV}$ for xanthene dyes $3 \mathrm{a}-\mathrm{e}$ and $6 \mathrm{a}-\mathrm{e}$, it is observed that for dyes $3 \mathrm{a}$ and 6a HOMO energy levels are at very low energy carboxylic groups present in the xanthene chromophore while $6 \mathrm{~b}$ and $6 \mathrm{e}$ have high HOMO energy levels due to the mesomorphic and the inductive effect of hydroxyl groups present in dye molecule. It is observed that there is little difference in the effect of electron donating groups on the HOMO energy levels while electron withdrawing groups definitely increase the energy of HOMO levels by increasing the energy gap between HOMO and LUMO.

Table 4: HOMO energy levels and band gap energy of xanthene dyes (3a-e, 6a-e)

\begin{tabular}{|c|c|c|}
\hline S.No. & $\mathbf{E}_{\mathbf{g}}(\mathbf{V})$ & HOMO $(\mathbf{e V})$ \\
\hline $3 \mathrm{a}$ & 2.87 & -7.54 \\
\hline $3 \mathrm{~b}$ & 2.82 & -7.27 \\
\hline $3 \mathrm{c}$ & 2.19 & -6.95 \\
\hline $3 \mathrm{~d}$ & 2.25 & -7.12 \\
\hline $3 \mathrm{e}$ & 2.53 & -7.33 \\
\hline 6a & 2.61 & -7.31 \\
\hline $6 \mathrm{~b}$ & 2.59 & -6.64 \\
\hline 6c & 2.25 & -7.05 \\
\hline $6 \mathrm{~d}$ & 2.46 & -6.96 \\
\hline 6e & 2.26 & -6.65 \\
\hline
\end{tabular}

\section{Fluorescence Studies:}

Fluorescence studies of all the dyes were made by preparing the aqueous solutions of dyes (3a-e and 6a-e) but there were only four dyes (3d, 3e, 6d and 6e) which were found to be highly fluorescent (Table S1, supporting information). These dyes fulfill the requirement of fluorescence that is the molecules should be highly conjugated and it should not undergo rotational or vibrational motions as a whole molecule. Although other dyes have also conjugated system of bonds, but molecules are flexible and undergo rotational or vibrational motions which are contrary to fluorescence. Fluorescence spectrum of all dyes 3a-e and 6a-e is shown below in figure S1 (supporting information), which was recorded by selecting different excitation wavelengths of the source. Fluorescence spectrum provides the intensity contribution to the observed emission at a given wavelength by different excitation wavelengths for the sample is exposed. The fluorescence spectrum showed only one there should be emission peak for all dyes except 3 a. The mission peak of lowest frequency was seen for $3 \mathrm{~d}$ and $6 \mathrm{~d}$ at $598 \mathrm{~nm}$ on excitation of aqueous solution at a concentration of $10^{-4}$ to $10^{-5} \mathrm{M}$.
Table: 5 Fluorescence data of Xanthene Dyes (3a-e) in water.

\begin{tabular}{|c|c|c|c|c|}
\hline Dye & Solvent & $\begin{array}{c}\text { Excitation } \\
\text { wavelength }\end{array}$ & $\begin{array}{c}\text { Emission } \\
\text { wavelength }\end{array}$ & $\begin{array}{c}\text { Stoke } \\
\text { Shift }\end{array}$ \\
\hline $6 \mathrm{a}$ & Water & $465 \mathrm{~nm}$ & $492 \mathrm{~nm}$ & 27 \\
\hline $6 \mathrm{~b}$ & Water & $488 \mathrm{~nm}$ & $505 \mathrm{~nm}$ & 17 \\
\hline $6 \mathrm{c}$ & Water & $541 \mathrm{~nm}$ & $557 \mathrm{~nm}$ & 16 \\
\hline $6 \mathrm{~d}$ & Water & $560 \mathrm{~nm}$ & $598 \mathrm{~nm}$ & 38 \\
\hline $6 \mathrm{e}$ & Water & $510 \mathrm{~nm}$ & $557 \mathrm{~nm}$ & 45 \\
\hline
\end{tabular}

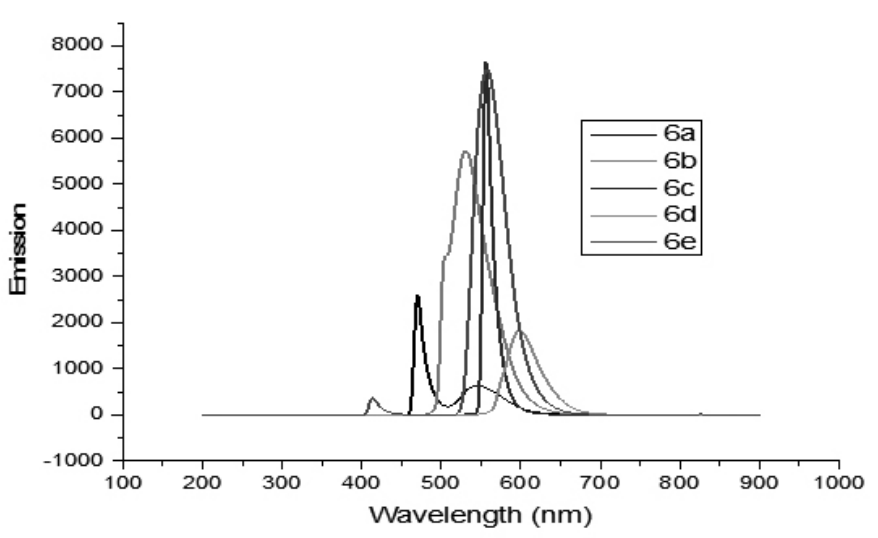

Figure 8: Fluorescence spectra of xanthene dyes (6a-e) in water

Effect of using dianhydrides for the synthesis of xanthene dyes is manifested in their emission spectra which have undergone a red shift as compared with rhodamine and fluorescein which have been synthesized from single anhydride (phthalic anhydride). So these dyes can be applied where usual xanthene fluorescent dyes are with preference requiring lower energy source for excitation.

Applications of Dyes:

Synthesized dyes $3 \mathrm{~d}, 3 \mathrm{e}, 6 \mathrm{~d}$ and $6 \mathrm{e}$ were tested for cell staining. Dyes exhibited differential staining of onion cells. Dyes $3 \mathrm{~d}$ and $6 \mathrm{~d}$ were concentrated inside the cell nuclei, while dyes $3 \mathrm{e}$ and $6 \mathrm{e}$ stained more the cell membrane. This differential staining was further judged from excitation of stained cells with UV-light, and yellowish light was emitted from the cell membrane and cell wall. Dyes $3 \mathrm{~d}$ and $6 \mathrm{~d}$ have dimethylamino groups on xanthene chromophore which have more interaction with cell nuclei being proteinaceous in nature and dyes adsorbed and stained through lone pair interaction. Dyes $3 \mathrm{e}$ and $6 \mathrm{e}$ have hydroxyl groups on xanthene chromophore which have more interaction with cell wall and cell membrane which are made up of carbohydrates and lipids, dyes interact through hydrogen bonding and absorbed more toward the cytoplasmic portion.

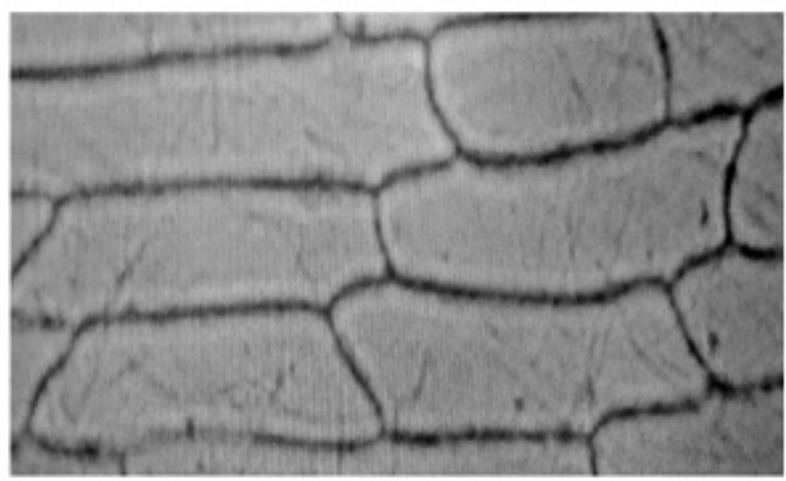

Figure 9: Dye 3e applied on onion cells, concentrated in cell membrane. 


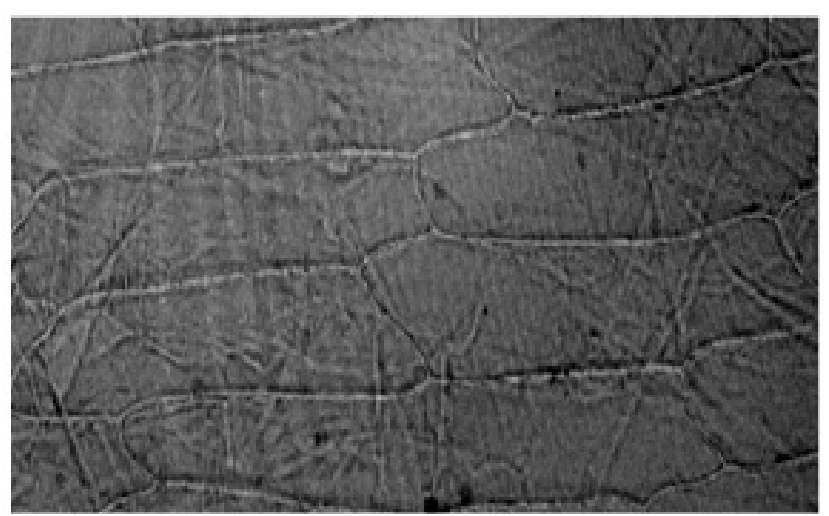

Figure 10: Dye 3e applied on onion cells, concentrated in cell membrane, emitting yellow fluorescence under UV-light.

\section{CONCLUSION}

Ten new water as well as polar solvent soluble xanthene dyes have been synthesized in high yields via a short and easy accessible route utilizing the ammonium chloride catalyst under solvent free conditions. Some of these dyes are colored in basic medium and colorless in acidic medium which exhibit absorptions in the range $434-552 \mathrm{~nm}$. The $\lambda_{\max }$ of all the dyes was found to be maximum in water, which was in accordance with the general rule that polar solvents shift $\pi-\pi^{*}$ to higher wavelength. Xanthene derivatives of resorcinol and 3-N,N'-dimethylaminophenol with 4, 4'-oxydiphthalic anhydride and $1,4,5,8$-naphthalenetetracarboxylic dianhydride exhibit remarkably high fluorescence in water at 557 and $598 \mathrm{~nm}$. Xanthene dyes containing 3-N, N'dimethylamino groups have lowest band gap and LUMO energy levels.

\section{REFERENCES}

1.- O. Piccolo, U. Azzena, G. Melloni, G. Delogu, E. Valoti, J. Org. Chem., 56, 183(1991).

2.- J.P. Poupelin, G. Saint-Rut, O. Fussard-Blanpin, G. Nar-ciss, G.U. Ernouf , R. Lakroix, Eur. J. Med. Chem., 13, 67 (1978)

3.- T. Nishiyama, K. Sakita, T.Fuchigami, T. Fukui, Polym. Deg. Stab., 62, 529(1998).

4.- S. Chatterjee, M. Iqbal, J.C. Kauer, J.P. Mallamo, S. Senadhi, S. Mallya, D . Bozyczko-Coyne, R. Siman, Bioorg. Med. Chem. Lett. 6, 1619 (1996).

5.- A.K. Bhattacharya, K.C. Rana, Mendel. Commun., 17, 247(2007)..

6.- P. Kumari, V. Yathindranath, S.M.S. Chauhan, Synth. Commun., 38, 637(2008)

7.- G. Saint-Ruf, A. De, H.T. Hieu, Naturwissenschaften., 62, 584(1975).

8.- R.M. Ion, D. Frackowiak, A. Planner, K. Wik- torowicz., Acta. Biochim. Polon., 45, 833(1998).

9.- C.C. Chang, Y.T.Yang, J.C. Yang, H.D. Wu, T. Tsai, Dyes. Pigm., 79, 170 (2008).

10.- M. Ahmad, T.A. King, K. Do-Kyeong, B.H. Cha, L. Jongmin, J. Phys. D. Appl. Phys., 35, 1473(2002).

11.- C.G. Knight, T. Stephens J. Biochem., 258, 683(1989).

12.- K. Hara, T. Horiguchi, T. Kinoshita, K. Sayama, H. Sugihara, H. Arakawa, Solar. Ener. Mater. Solar. Cells., 64, 115(2000).

13.- B. Pradhan, S.K. Batabyal, A.J. Pal, Solar. Ener. Mater. Solar. Cells., 91, 769(2007).

14.- E. Guillen, F. Casanueva, J.A. Anta, A. Vega-Poot, G. Oskam, R. Alcantara, C. Fernandez-Lorenzo, J. Martin-Calleja, J. Photochem. Photobio A: Chemistry., 200, 364(2008).

15.- G.D. Sharma, P. Balraju, M. Kumar, M.S. Roy, Mater. Sci. Engin B., 162, 32(2009).

16.- Z.Z. Chu, D. Wang, C. Zhang, F.H. Wang, H.W. Wu, Z.B. Lv, S.C. Hou, X. Fan, D.C. Zou, Synth. Metals., 162, 614(2012).

17.- G. Casiraghi, G. Casnati, M. Cornia, Tetrahedron Lett., 14, 679(1973).

18.- J.Q. Wang, R.G. Harvey, Tetrahedron., 58, 5927(2002).

19.- A. Jha, J. Beal, Tetrahedron Lett., 45,: 8999(2004).

20.- B. Karami, Z. Zare, K. Eskandari, Chem. Papers., 67, 145(2013).

21.- F.Q. Ding, L.T. An, J.P. Zou, Chinese. J. Chem., 25, 645(2007).

22.- L.M. Wang, Y.Y. Sui, L. Zhang, Chinese. J. Chem., 26, 1105(2008).
23.- S. Urinda, D. Kundu, A. Majee, A. Hajra, Heteroatom. Chem., 20, 232(2009).

24.- B. Wang, P.H. Li, Y.C. Zhang, L. Wang, Chinese. J. Chem., 28, 2463(2010)

25.- E. Soleimani, M.M. Khodaei, A.T.K. Koshvandi, Chinese. Chem. Let., 22, 927(2011).

26.- K. Gong, D. Fang, H.L. Wang, X.L. Zhou, Z.L. Liu, Dyes. Pigm., 80, 30(2009).

27.- A.R. Hajipour, Y. Ghayeb, N. Sheikhan, A.E. Ruoho, Synlett., 5, 741(2010).

28.- A. Rahmatpour, Monatshefte Fur Chemie., 142, 1259(2011).

29.- D. Prasad, M. Nath, Catalysis. Sci. Technol., 2, 93(2012).

30.- I. Mielgo, M.T. Moreira, G. Feijoo, J.M. Lema, J. Biotech., 89, 99(2001).

31.- N. Jaggi, K. Yadav, M. Giri, Ind. J. Pur. App. Phys., 51, 742(2013).

32.- Y. Zagranyarski, L. Chen, D. Jänsch, T. Gessner, C. Li, K. Mullen, Org. lett., 16, 2814(2014).

33.- J.L. Weisman, T.J. Lee, F. Salama, M. Head-Gordon, Astrophysical. J., 587, 256(2003).

34.- Y. Na, J. Pharm. Pharmacol., 61, 707(2009). 